\title{
The Effect of Glucocorticoids on Plasma Insulin- Like Growth Factor I Concentration in the Rat Fetus
}

\author{
H. DAVID MOSIER, JR., E. MARTIN SPENCER, LYLE C. DEARDEN, AND \\ REGINA A. JANSONS \\ Department of Pediatrics and Anatomy, University of California, Irvine, and the Childrens Hospital, \\ San Francisco, California
}

\begin{abstract}
Radioimmuno- and radioreceptor-assayable insulin-like growth factor I (IGF-I) concentration was determined in plasma pools of rat fetuses on gestation day 21 following treatment of the pregnant rats with pharmacologic doses of betamethasone, dexamethasone, or cortisone on gestation days 12 and 13. Dose-related reduction of plasma concentration of IGF-I occurred after betamethasone or dexamethasone treatment. There was no change in IGF-I concentration after cortisone treatment. The changes in fetal IGF-I concentration after steroid treatment were parallel between the two assays. Comparison of the results with previous data showing the effects of identical treatment of pregnant rats on fetal body and organ growth suggests that the IGF-I changes correlate better with reduction of liver/body ratio than with reduction of body weight. The findings indicate that growth retardation after steroid treatment in the fetus is in part the result of factors other than IGF-I. This may include a direct effect of the glucocorticoids on skeletal tissue. Reduced IGF-I concentration may contribute to the growth deficit. (Pediatr Res 22: 92-95, 1987)
\end{abstract}

\section{Abbreviations}

GH, pituitary growth hormone

IGF-I, insulin-like growth factor I, somatomedin-C

IGF-II, insulin-like growth factor II, MSA

RIA, radioimmunoassay

RRA, radioreceptor assay

SDS-PAGE, polyacrylamide gel electrophoresis in the presence of sodium dodecyl sulfate

HPM, human placental membrane

Glucocorticoid treatment in the pregnant rat produces doserelated retardation of fetal somatic and visceral growth (1-4). The mechanism of glucocorticoid-induced growth impairment is unclear, although pathologic alteration of chondrocytes has been observed after high dose glucocorticoid administration to the fetal (5) and postnatal rat (6).

The role of IGFs (somatomedins) in glucocorticoid-induced fetal growth retardation is also not clear. The IGFs may serve as mitogens for fetal tissues as suggested by the presence in fetal tissues of specific membrane receptors for the IGFs, and the capability of multiple fetal tissues to synthesize IGF (7).

Received October 17, 1986; accepted February 13, 1987

Address for correspondance and reprints Dr. H. D. Mosier, Department of Pediatrics, University of California, Irvine, CA 92717.

Supported by NIH Grants HD 07074 and 12034.
The present study was carried out in order to elucidate the role of IGF-I in growth retardation of the glucocorticoid-treated rat fetus. Three different glucocorticoids were used in order to test for possible differences due to molecular specificity. Inasmuch as IGF-I is growth hormone dependent (8) plasma growth hormone was also determined in two of the steroid groups.

\section{METHODS}

Long-Evans rats obtained from Simonsen Labs (Gilroy, CA) were housed in the Animal Resource Facility of the University of California, Irvine, CA. Except during breeding, all animals were housed individually in stainless steel cages (hanging type) measuring $7 \times 7 \times 10$ inches in size. The stock diet was Purina Lab Chow, St. Louis, MO. Food and tap water were provided ad libitum. Room air was fresh and filtered and was kept at $20.5-23.9^{\circ} \mathrm{C}$; light/dark periods of $14 / 10 \mathrm{~h}$ were automatically controlled. Animal handling was carried out by the same attendant.

All experiments were carried out during the first pregnancy. The day of appearance of the vaginal plug was designated day 1 of gestation. All rats were weighed on day 12 of gestation prior to injections and again on day 21 . At the time of weighing on day 12 the pregnant rats were sorted into experimental and control groups on the basis of body weight in order to provide similar means and variance of body weight between groups. The pregnant rats were injected subcutaneously on days 12 and 13 of gestation with one of the following: a mixture of betamethasone sodium phosphate and betamethasone acetate suspension (Celestone Soluspan, Schering Corp. Kenilworth, NJ) in a dose of 0.18 or $0.42 \mathrm{mg} /$ injection, dexamethasone acetate suspension (Decardron-LA, Merck, Sharp \& Dohme West Point, PA) in a dose of 0.12 or $0.24 \mathrm{mg} /$ injection, or cortisone acetate suspension (Cortone Acetate, Merck, Sharp \& Dohme) in a dose of $50 \mathrm{mg} /$ injection. The lower dose of betamethasone and dexamethasone, based on the mean weights of the pregnant rats, was approximately 0.4 and $0.6 \mathrm{mg} / \mathrm{kg}$, respectively. In terms of body weight the lower dose is somewhat greater than that used for betamethasone and dexamthasone in the prevention of respiratory distress syndrome in the human. The dose in that case may be 12 $\mathrm{mg} / \mathrm{day}(9,10)$ or $0.18 \mathrm{mg} / \mathrm{kg}$ in the case of a $65-\mathrm{kg}$ woman. The cortisone dose, approximately $140 \mathrm{mg} / \mathrm{kg}$, was made relatively large in proportion to the antiinflammatory potencies of betamethasone and dexamethasone doses in order to overcome the well-known resistance of the rat to teratogenic influences by cortisone $(11,12)$ and to lower the maternal weight gain to the same range resulting from betamethasone and dexamethasone treatments. Control rats were injected with physiologic saline. Fetuses were removed under ether anesthesia on day 21 of gestation and bled from the neck into micro tubes containing 
dry heparin. The tubes were promptly centrifuged and the plasma pooled for each litter of fetuses. The plasma samples were stored at $-60^{\circ} \mathrm{C}$ pending assay.

Human IGF-I was purified by the method of Spencer et al. (13). Human Cohn fraction IV-1 was extracted with acid-ethanol and the IGFs precipitated by acetone. The acetone precipitate was chromatographed on Sephadex G-75 and G-50, both in 1 M acetic acid. The IGF containing peak was subjected to isoelectric focussing on a flat bed of Sephadex G-75. The IGF focussing at $\mathrm{pH} 8.3$ was eluted and purified to homogeneity by reverse phase high-performance liquid chromatography on a $\mathrm{C}_{18}$ column using an acetonitril gradient in $0.1 \%$ trifluoracetic acid. Homogenity was established by SDS-PAGE and a single N-terminal residue. The identity of IGF-I with somatomedin-C was verified by an amino acid composition in excellent agreement with the known integral values for this peptide, determination of the N-terminal 20 residues by microsequence analysis, and C-terminal carboxypeptidase digestion. The insulin-like activity in isolated fat cells of the purified IGF-I agreed with that of a pure preparation of IGF-I (courtesy of Herington AC) (14). It was biologically active in several assays: chicken embryo fibroblasts, Balb/c-3T3 cell progression assay, and cartilage sulfation activity performed by, respectively, Nissley et al. (15), Stiles et al. (16) and Jennings et al. (17). In the cell progression assay the maximum effect was achieved at $5 \mathrm{ng} / \mathrm{ml}$ which compares favorably with IGF-I purified by others.

The IGF-I antibody was prepared by Reber and Liske (18) Rabbits were immunized with human IGF-I purified by Ritschard and Roncari at Hoffman-La Roche (Basel, Switzerland) from human Cohn fraction IV. The immunizing material contained a single peptide as determined by physicochemical and $\mathrm{N}$-terminal microsequence analysis, performed at a level that would detect greater than $10 \%$ contamination. This antibody has been used in our RIA (19) and that of Zapf et al. (20). Its crossreactivity with rat somatomedin-C is $35 \%$ and with rat and human IGF-II it is $3 \%$. No cross-reactivity was observed with growth hormone, prolactin, insulin, glucagon, epidermal growth factor, and bradykinin.

IGF-I was iodinated using solid-phase lactoperoxidase beads according to the protocol supplied by BioRad, Richmond, CA. The labeled polypeptide was separated from the free ${ }^{125} \mathrm{I}$ by Sephadex G-50 chromatography in $50 \mathrm{mM}$ Tris- $\mathrm{HCl} \mathrm{pH} 7.4$ containing $0.25 \%$ human serum albumen. The specific activity averaged $200 \mu \mathrm{Ci} / \mu \mathrm{g}$.

Several modifications have been incorporated into the IGF-I RIA (19). Samples were extracted with acid-ethanol to separate the binding protein by a modification of the method of Daughaday et al. (21). After extraction, samples were dried in a Speed Vac Concentrator, Savant Instruments, Farmingdale, NY, dissolved in assay buffer, and adjusted to pH 7.4 with $2 \mathrm{M}$ Tris. The RIA buffer was $30 \mathrm{mM}$ phosphate pH 7.4 containing $0.25 \%$ human serum albumen and $0.02 \%$ sodium azide. The assay volume was $0.4 \mathrm{ml}$ and contained the rabbit anti-IGF-I antiserum in a final dilution of $1: 22,000$ and $15,000 \mathrm{cpm}$ of ${ }^{125} \mathrm{I}$-IGF-I. The incubation was carried out at $4^{\circ} \mathrm{C}$ for $18 \mathrm{~h}$ and the free ${ }^{125} \mathrm{I}-\mathrm{IGF}$ I was separated from bound by double antibody plus PEG precipitation. Fifty percent displacement in the assay was at 2 $\mathrm{ng}$; the sensitivity was $0.4 \mathrm{ng}$. The interassay and intraassay variations were 12 and $15 \%$, respectively. The mean \pm SD values for normal adults and acromegalics are $260 \pm 80$ and $812 \pm 90$ $\mathrm{ng} / \mathrm{ml}$.

Details of the IGF-I HPM radioreceptorassay have been reported except that samples were extracted with acid-ethanol and the IGF-I used as ligand and standard was purified as described above (22). The receptor specificity of the HPM radioreceptorassay is such that it is primarily a measure of IGF-I but other IGFs cross-react and it may be possible to detect large changes in their concentration.

GH was determined in duplicate by RIA (23). All samples in the present study were assayed in the same run. The interassay and intrassay variations for the GH RIA were 6.7 and $6.2 \%$, respectively.

Statistical significance was determined by a one-tailed Student's $t$ test.

\section{RESULTS}

Plasma IGF-I. The results of determinations of IGF-I by RIA and RRA and of GH are shown in Table 1. The single dose level of cortisone resulted in no significant change by either assay This was also true of the low dose levels of betamethasone and dexamethasone. The high dose levels of both betamethasone and dexamethasone resulted in a significant decrease of IGF-I by either assay. The changes were approximately proportionate between the two assays. GH concentration was decreased in the two betamethasone pools; however, the result was significant only at the $0.18-\mathrm{mg}$ dose level. Greater variability accounted for the lack of significance at the higher dose level. There was no decrease in $\mathrm{GH}$ concentration with either dose of dexamethasone.

\section{DISCUSSION}

The present experiments indicate significant and parallel reduction of immuno- and receptor-assayable IGF-I in fetal plasma after treatment of the pregnant mothers with high doses of either betamethasone or dexamethasone. Lower doses of either steroid did not produce significant differences from control levels. Treatment with cortisone produced no change in IGF-I concentration as measured by either assay. Betamethasone treatment resulted in decreased fetal plasma $\mathrm{GH}$ concentration; dexamethasone had no effect on $\mathrm{GH}$ concentration.

We have previously reported the effects on fetal and organ weights in identically treated pregnant rats (4). Fetal body weight was significantly reduced by betamethasone and dexamethasone in both low and high doses and by cortisone in the same dose used in the present experiments. Cortisone treatment resulted in a quantitatively minor, although significant, reduction of the liver/body weight ratio. Betamethasone and dexamethasone resulted in a greater reduction of liver/body weight ratio. The relative preservation of the liver/body ratio in cortisone treatment may account for the normal levels of IGF-I in the cortisone-

Table 1. IGF-I concentrations in fetal plasma pools determined by RIA and RRA (mean $\pm S E)^{*}$

\begin{tabular}{|c|c|c|c|c|c|c|c|c|c|}
\hline Group & $\begin{array}{c}\text { Dose } \\
\text { (mg/day) }\end{array}$ & $N_{p}$ & $N_{\mathrm{I}}$ & $\begin{array}{c}\text { RIA } \\
(\mathrm{ng} / \mathrm{ml})\end{array}$ & $p$ & $\begin{array}{c}\text { RRA } \\
(\mathrm{ng} / \mathrm{ml})\end{array}$ & $p$ & $\begin{array}{c}\mathrm{GH} \\
(\mathrm{ng} / \mathrm{ml})\end{array}$ & l) \\
\hline Control & 0 & 6 & $7-13$ & $59.5 \pm 1.1$ & & $223 \pm 18$ & & $190 \pm 21$ & \\
\hline Cort & 50.0 & 5 & $10-14$ & $55.8 \pm 2.4$ & NS & $232 \pm 23$ & NS & & \\
\hline Bet & 0.18 & 5 & $7-11$ & $53.4 \pm 5.1$ & NS & $182 \pm 17$ & NS & $146 \pm 7$ & $<0.05$ \\
\hline Bet & 0.42 & 5 & $7-12$ & $36.8 \pm 3.3$ & $<0.005$ & $170 \pm 16$ & $<0.05$ & $148 \pm 21$ & NS \\
\hline Dex & 0.12 & 5 & $8-12$ & $52.9 \pm 6.1$ & NS & $249 \pm 9$ & NS & $198 \pm 32$ & NS \\
\hline Dex & 0.24 & 5 & $8-12$ & $39.0 \pm 3.5$ & $<0.005$ & $151 \pm 6$ & $<0.005$ & $182 \pm 12$ & NS \\
\hline
\end{tabular}

* Cort, cortisone; Bet, betamethasone; Dex, dexamethasone; $\mathrm{N}_{\mathrm{P}}$, number of litters pooled; $\mathrm{N}_{\mathrm{F}}$, number of fetuses/pool, given as a range; $p$, probability by one-tailed $t$ test. 
treated fetuses. The reduction in IGF-I after betamethasone and dexamethasone correlated with the size of the dose in the present experiments as did the previously reported reduction in liver/ body ratio (4).

The fetal skeleton is not uniformly affected at all dose levels of glucocorticoids. Using similar dosage schedules we have found that the lower dose of betamethasone or dexamethasone stimulated maturation of the appendicular skeleton and slowed maturation of the axial skeleton in the fetal rat, while the higher dose retarded maturation in both regions (24). In addition, the effects on fetal organ weight have been shown to be disproportionate, with relatively greater impairment of the liver/body weight ratio than of the corresponding organ/body weight ratios of brain, heart, or kidneys (4). It is evident from those experiments that there are regional and tissue differences in the response to the steroids.

Under certain in vitro conditions glucocorticoids stimulate skeletal growth and maturation. Hydrocortisone at $14 \mu \mathrm{M}$ in the media has been found to extend lifespan and to increase the rate of proliferation of cells and the rate of DNA synthesis in cultures of fibroblast-like human cells. Higher concentrations were suppressive (25). It has been shown that virus-transformed chick embryo fibroblasts lose the inhibitory response to hydrocortisone in concentrations $10^{5}$ times that capable of producing $50 \%$ inhibition of normal cells (26). Steroids may directly stimulate cartilage maturation by amplifying the activity of pituitary and brain-derived growth factors (27). That chondrocytes are capable of producing IGF-I in situ (28) suggests that regional differences may result from differences in perfusion of the regions with exogenous steroid, differences in numbers of IGF-I-producing chondrocyte clones, or other, as yet undetermined, factors having an influence on the paracrine actions of IGF-I.

Recent findings indicate that growth hormone may directly regulate clonal expansion of differentiated chondrocytes producing IGF-I in the growth plate (28). In the rat fetus at 17 days gestation plasma levels of IGF-I are slightly below the maternal plasma level, while IGF-II levels greatly exceed the maternal concentration (29). High levels of fetal plasma IGF-II relative to maternal concentration of IGF-II and to fetal IGF-I concentration have also been observed in the sheep (30) and guinea pig (31). While it has been shown that somatomedin (IGF-I) has a mitogenic effect in fetal human cartilage (32), the relevance of fetal plasma concentration of IGF to fetal skeletal growth is uncertain in view of the evidence that IGF-I is synthesized in many organs (33). However, radioimmunoassayable plasma IGF-I of human fetuses, aged 15-23 wk, was found to correlate significantly with fetal body weight, placenta weight, crown-rump length, and crown-heel length; no correlation was found between radioimmunoassayable IGF-II and body weight, length, placenta weight, or gestational age (34). Liver and serum IGF-I in fetal rats correlated with fetal weight in growth retardation produced by uterine artery ligation (35). Recent studies have shown divergence patterns of thymidine uptake stimulating activity from immunoassable IGF-I concentration in blood of human fetuses at gestational ages from 21-28 wk (36) and cord blood of human neonates (37) suggesting that factors other than IGF contributing to thymidine activity may also play a role in fetal growth.

The reduction in $\mathrm{GH}$ concentration in the betamethasonetreated fetuses has its counterpart in the human exposed in late gestation to betamethasone (38). Comparable human data are lacking for dexamethasone. In an earlier study, we found no difference between the two steroids in their effect on fetal growth and on brain/body and liver/body weight ratios. On the other hand, marked differences existed with regard to heart/body, kidney/body, and adrenal/body weight ratios (4). The differences between the tissue effects of betamethasone and dexamethasone are thus not likely to be related to differences in placental passage but, rather, to modulation of the steroid effect by differences in concentration and affinity of specific tissue steroid receptors. An example of steroid receptor specificity occurs in the fetal lung cell line W1-38 which has high affinity binding sites which are steroid-molecular structure specific (39). A difference in hypothalamic and/or pituitary tissue steroid receptors in the fetal rat could account for the present observations.

Acknowledgment. Technical assistance was provided by Rosalinda C. Roberts.

\section{REFERENCES}

1. Parvez H, Ismahan G, Parvez S 1976 Fetal growth retardation and mortality by chronic dexamethasone administration to pregnant rats. J Endocrino 71:159-160

2. Lemmen K, Maurer W, Trieb H, Ueberberg H, Seeliger H 1977 Morphologic changes in the adrenal glands of fetal and newborn rats following administration of glucocorticoids to the mother during pregnancy. Beitr Pathol 160:361-380

3. Roland H, Reinboth R, Neumann F 1977 Einfluss von Glucocorticosteroiden auf die Geschleshsdifferenzierung von Ratten. Endocrinologie 69:181-194

4. Mosier HD Jr, Dearden LC, Jansons RA, Roberts RC, Biggs CS 1982 Disproportionate growth of organs and body weight following glucocorticoid treatment of the rat fetus. Dev Pharmacol Ther 4:89-105

5. Dearden LC, Mosier HD Jr, Brundage M, Thai C, Jansons R 1986 The effects of different steroids on costal and epiphyseal cartilage of fetal and adult rats. Cell Tissue Res 246:401-412

6. Dearden LC, Mosier HD Jr 1972 Long-term recovery of chondrocytes in the tibial epiphyseal plate in rats after cortisone treatment. Clin Orthop 87:322331

7. D'Ercole AJ, Underwood LE 1985 Somatomedin in fetal growth. Pediat Pulmonol 1(3 suppl):99-106

8. Daughaday WH 1981 Growth hormone and the somatomedins. In: Daughaday WH (ed) Endocrine Control of Growth. Elsevier, New York, pp 1-24

9. Papageorgiou AN, Desgranges MF, Masson M, Colle E, Shatz R, Gelfand MM 1979 The antenatal use of betamethasone in the prevention of respiratory distress syndrome: a controlled double-blind study. Pediatrics 63:73-79

10. Taeusch HW, Frigoletto F, Kitzmiller J, Avery ME, Hehre A, Fromm B Lawson E, Neff RK 1979 Risk of respiratory distress syndrome after prenatal dexamethasone treatment. Pediatrics 63:63-72

11. Walker BE 1971 Induction of cleft palate in rats with antiinflammatory drugs. Teratology 4:39-42

12. Shah RM, Kilistoff A 1976 Cleft palate induction in hamster fetuses by glucocorticoid hormones and their synthetic analogues. J Embryol Exp Morphol 36:101-108

13. Spencer EM, Ross M, Smith B 1983 The identity of human insulin-like growth factors I and II with somatomedins C and A. Homology with rat IGF I and II. In: Spencer EM (ed) Insulin-Like Growth Factors/Somatomedins. Walter de Gruyter, New York, pp 81-96

14. Herington AC, Kuffer AD 1983 IGF-like characteristics of an acidic nonsuppressible insulin-like activity. In: Spencer EM (ed) Insulin-Like Growth Factors/Somatomedins. Walter de Gruyter, New York, pp 121-125

15. Nissley SP, Rechler MM, Moses AC, Short PA, Podskalny JM 1977 Proinsulin binds to a growth peptide receptor and stimulates DNA synthesis into embryo fibroblasts. Endocrinology 101:708-716

16. Stiles CD, Capone GT, Scher CD, Antoniades HN, Van Wyk JJ, Pledger WI 1979 Dual control of cell growth by somatomedin and platelet derived growth factor. Proc Natl Acad Sci USA 76:1279-1283

17. Jennings J, Buchanan F, Freeman D, Garland JT 1980 Stimulation of chick embryo cartilage sulfate and thymidine uptake: comparison of human serum purified somatomedins and other growth factors. J Clin Endocrinol Metab 51:1166-1170

18. Reber K, Liske R 1976 Radioimmunoassay for non-suppressible insulin-like activity. Hormone Res 7:201-208

19. Lanes R, Plotnick LP, Spencer EM, Daughaday WH and Kowarski AA 1980 Dwarfism associated with normal serum growth hormone and increased bioassayable, receptorassayable, and immunoassayable somatomedin. J Clin Endocrinol Metab 50:465-488

20. Zapf J, Morell B, Walter H, Laron Z, Froesch ER 1980 Serum levels of the insulin-like growth factor (IGF) and its carrier. Acta Endocrinol (Copenh) 95:505-517

21. Daughaday WH, Parker KA, Borowsky S, Trivedi B, Kapadia M 1982 Measurement of somatomedin-related peptides in fetal, neonatal, and maternal rat serum by insulin-like growth factor (IGF) I radioimmunoassay, IGF-II radioreceptor assay (RRA), and multiplication-stimulating activity RRA after acid-ethanol extraction. Endocrinology 110:575-581

22. Spencer EM, Uthne K, Arnold W 1979 Growth impairment with elevated somatomedin levels in children with chronic renal insufficiency. Acta Endocrinol (Copenh) 91:36-48

23. Sinha YN, Wilkins JN, Selby F, VanderLaan WP 1973 Pituitary and serum growth hormone during undernutrition and catch-up growth in young rats. Endocrinology 92:1768-1771

24. Mosier HD Jr, Dearden LC, Roberts RC, Jansons RA, Biggs CS 1981 Regional differences in the effects of glucocorticoids on maturation of the fetal skeleton of the rat. Teratology 23:15-24

25. Cristofalo VJ 1975 The effect of hydrocortisone on DNA synthesis and cell division during aging in vitro. Adv Exp Med Biol 53:7-22 
26. Fodge DW, Rubin H 1975 Differential effects of glucocorticoid on DNA synthesis in normal and virus-transformed chick embryo cells. Nature 257:804-806

27. Gospodarowicz D 1974 Localization of a fibroblast growth factor and its effect alone and with hydrocortisone on 3T3 cell growth. Nature 249:123-127

28. Nilsson A, Isgaard J, Lindahl A, Dahlström A, Skottner A, Isaksson OGP 1986 Regulation by growth hormone of number of chondrocytes containing IGF-I in rat growth plate. Science 233:571-574

29. Deleted in proof

30. Gluckman PD, Butler JH 1983 Parturition-related changes in insulin-like growth factor-I and factor-II in the perinatal lamb. J Endodocrinol 99:223232

31. Daughaday WH, Yanow CE, Kapadia M 1986 Insulin-like growth factors I and II in maternal and fetal guinea pig serum. Endocrinology 119:490-494

32. Ashton IK, Spencer EM 1983 Effect of partially purified somatomedin on human fetal and postnatal cartilage in vitro. Early Human Dev 8:135-140

33. D'Ercole AJ, Stiles AD, Underwood LE 1984 Tissue concentrations of somatomedin C: Further evidence for multiple sites of synthesis and paracrine or autocrine mechanisms of action. Proc Natl Acad Sci USA 81:935-939
34. Ashton IK, Zapf J, Einschenk I, MacKenzie IZ 1985 Insulin-like growth factors (IGF) 1 and 2 in human foetal plasma and relationship to gestational age and foetal size during midpregnancy. Acta Endocrinol (Copenh) 1 10:558563

35. Vileisis RA, D'Ercole AJ 1986 Tissue and serum concentrations of somatomedin-C/insulin-like factor $I$ in fetal rats made growth retarded by uterine artery ligation. Pediatr Res 20:126-130

36. Theriot-Prevost G, Daffos F, Forestier F, Job JC 1986 Serum somatomedin C, bioassayable growth-promoting activity (thymidine activity), and transferrin in human fetuses: in utero study. Pediatr Res 20:71-73

37. Schimpff RM, Bozzola M, Zapf J 1985 Serum thymidine activity and insulinlike growth factors in the neonatal period. Acta Endocrinol (Copenh) 110:140-144

38. Ballard PL, Gluckman PD, Liggins GC, Kaplan SL, Grumbach MM 1980 Steroid and growth hormone levels in premature infants after prenatal betamethasone therapy to prevent respiratory distress syndrome. Pediatr Res 14:122-127

39. Iacobelli S, Ranelletti F, Sica G, Barile G 1978 Glucocorticoid receptors in human fetal lungs. J Endocrinol Invest 1:209-213 